\title{
Determination of Benthic Macroinvertebrate Fauna and Some Physicochemical Properties of Kanak Dam Lake (Şarkışla-Sivas)
}

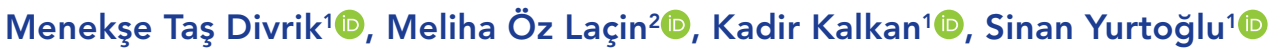

Cite this article as: Tas Divrik, M., Oz Lacin, M., Kalkan, K., \& Yurtoglu, S. (2021). Determination of benthic macroinvertebrate fauna and some physicochemical properties of Kanak Dam Lake (Şarkışla-Sivas). Aquatic Sciences and Engineering, 36(1), 1-10.

ORCID IDs of the author: M.T.D. 0000-0002-4828-2575; M.Ö.L. 0000-0002-3014-8060; K.K. 0000-0001-6849-4498; S.Y. 0000-0002-4565-6842

'Şarkısla Aşık Veysel Vocational School, Sivas Cumhuriyet University, Şarkışla, Sivas, Turkey

${ }^{2}$ Şarkışla Ziraat Odası, Toprak Analiz Laboratuvarı, Şarkışla, Sivas, Turkey

\section{Submitted:}

05.03.2020

Revision Requested: 09.04.2020

Last Revision Received: 11.07.2020

\section{Accepted:}

15.07.2020

Online published:

07.10.2020

Correspondence:

Menekşe Taş Divrik

E-mail:

menekse.tas@cumhuriyet.edu.tr

(C) Copyright 2021 The Author(s) Available online at

https://dergipark.org.tr/ase

\begin{abstract}
This paper aims to identify the benthic macroinvertebrate fauna and some physicochemical characteristics of Kanak Dam Lake located in Şarkışla, Sivas. For this, water and sediment samples were taken from 4 stations of the lake between August 2016 to July 2017 at monthly intervals, and a detailed physicochemical analysis was carried out on these samples. While the identification of benthic macroinvertebrates was made to the lowest possible taxa (species, genus or families), some physicochemical characteristics of the lake water such as temperature, $\mathrm{pH}$, electrical conductivity, dissolved oxygen, $\mathrm{SO}_{4}, \mathrm{PO}_{4}, \mathrm{NO}_{3}-\mathrm{N}, \mathrm{NO}_{2}-\mathrm{N}, \mathrm{Mg}, \mathrm{Ca}$, total hardness, salinity and $\mathrm{Cl}$ levels were determined using various titrimetric and spectrophotometric methods. As a result, a total of 30 taxa were identified and were classified as Oligochaeta, Chironomidae, Gastropoda and other Insecta (Ephemeroptera, Trichoptera, Hemiptera (adult), Odonata, Plecoptera and larval Coleoptera). All the identified taxa were determined as the first records for the lake. While the temperature, $\mathrm{pH}$, electrical conductivity, dissolved oxygen, chloride and sulfate levels were found to have the first class quality according to Turkey's water control regulations the $\mathrm{NO}_{3}-\mathrm{N}$ and $\mathrm{NO}_{2}-\mathrm{N}$ levels in the lake were found to have the second and third class water quality, respectively. The total hardness of the lake water was found to be at lighthard water quality The Shannon Weiner diversity index for macrobenthic fauna of the dam lake was found to be 0.64 on average. The sampling stations and months were evaluated also statistically by using the Bray-Curtis Cluster Index in terms of the distribution of the benthic macroinvertebrates and physicochemical parameters.
\end{abstract}

Keywords: Water quality, Oligochaeta, Benthic macroinvertebrates, Dam lake

\section{INTRODUCTION}

Dams are structures that have been built for water irrigation of agricultural land to meet the water needs of mankind. Today's modern dams have strategic importance since they play major roles in energy production in developing countries. They also have significant influence in agricultural activities. The Kanak Dam located on the Kanak stream in the town of Şarkışla of Sivas province was built with the intention to solve the drinking and potable water problem of the towns of Şarkışla, Gürçayır and Cemel as well as for flood prevention and irrigation of the agricultural land in the area. Standing at 37.5 me- ters high, the Kanak Dam has a surface level of 1.84 square kilometers and an irrigation area of $2270 \mathrm{ha}$; the core of the dam was made of a mixture of clay, gravel and core sand (DSi, 2016). There have been many studies on the dam lakes in Turkey; Kırgız (1988), Ahıska, (1999), Çamur-Elipek (2003); Balık et al., (2004); Taşdemir \& Ustaoğlu (2005); Yıldız \& Balık (2006); Arslan et al., (2007); Yıldız et al., (2008); Ersan et al., 2009; Taşdemir et al., (2010); Fındık \& Göksu (2012); Özbek et al., (2016). There are a few studies on the dam lakes in the region; Dirican (2008); Mutlu et al., (2014); Dirican (2015); Yıldız \& Karakuş (2018). 
There has been no study on the macrobenthic invertebrate fauna and physicochemical parameters of the Kanak Dam Lake thus far. The aim of this study is to identify the benthic macroinvertebrate fauna and physicochemical characteristics of the Kanak Dam Lake. This study further aimed to contribute to the taxonomical and environmental studies performed in Turkish dam lakes.

\section{MATERIALS AND METHODS}

The study area is located $10 \mathrm{~km}$ southeast of the city center of Şarkışla, within the area surrounded by Cemel, Döllük, Konakyazı and Samankaya villages. The water and sediment sample-taking took place at four different stations between August 2016 and July 2017 at monthly intervals. The location of the Kanak Dam Lake and the sampling stations are presented in Figure 1.

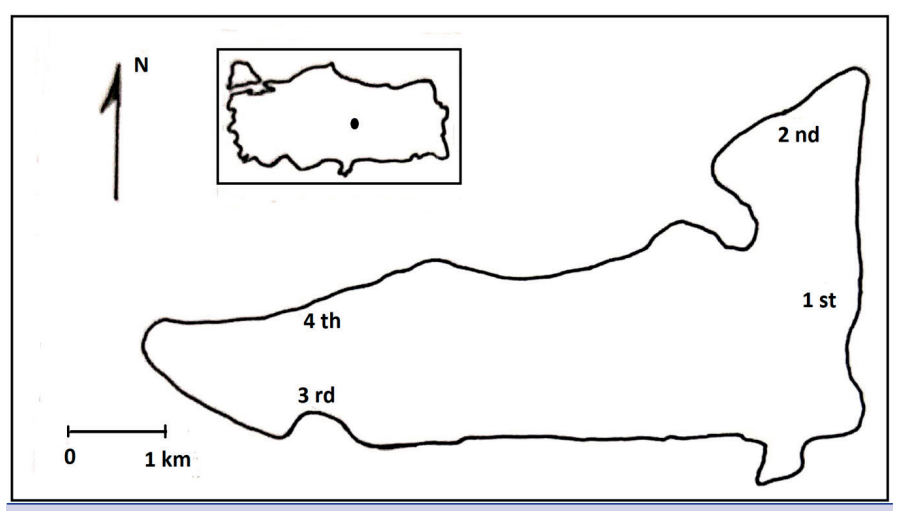

Figure 1. The location of Kanak Dam Lake and the sampling stations.

Station $\mathbf{1}$ is located just behind the dam. Station $\mathbf{2}$ is located in a narrow channel area of the lake and has rich vegetation. Station $\mathbf{3}$ is part of the lake before joining the Kanak stream. Station 4 is located where the stream meets the lake and has rich vegetation, being the shallowest part of the lake. Water temperature (using a basic thermometer), electrical conductivity (using a conductivity meter) and $\mathrm{pH}$ level (using a $\mathrm{pH}$ meter) were measured in the field. In order to measure and analyze the other parameters, water samples were taken using the Ruttner sampler. The samples were then transported to the laboratory in 2 liter dark colored bottles. The analyses were carried out using classical titrimetric and spectrophotometric methods proposed by Egemen \& Sunlu (1999). The water quality of the samples were determined according to the Surface Water Control Regulation for inland waters in Turkey (Anonymous, 2016). Benthic macroinvertebrate samples were taken from each station twice by using an Ekman Birge grab $(15 \times 15 \mathrm{~cm})$ and washed with mesh sieves of $1.19 \mathrm{~mm}, 0.595 \mathrm{~mm}$, and $0.297 \mathrm{~mm}$. All obtained organisms were immediately fixed in $4 \%$ formaldehyde in the field and then transferred to $70 \%$ ethanol. The benthic macroinvertebrate samples were identified to the lowest possible taxon (species, genus or families) under a stereomicroscope in the laboratory. Brinkhurst $(1971,1978)$, Brinkhurst \& Jamieson (1971), Brinkhurst \& Wetzel (1984), Kathman \& Brinkhurst (1998), Milligan \& Michael (1997), Sperber (1948, 1950), Timm (1999) and Wetzel et al., (2000) were used as a guideline for identifying Oligochaeta specimens. Oliver et al., (1978), Saether (1980), Cranston (1982), Pinder \& Reiss (1983), Fittakau \& Roback (1983) were used for identification of larval Chironomids. McDonald et al., (1991) and Merritt \& Kenneth, (1984) were used for identifying the other insecta specimens. The number of individuals per $\mathrm{m}^{2}$ and their densities as (\%) of the taxa were also evaluated. All the physicochemical data obtained were transformed by using statistical techniques on LogBase10 in Microsoft Office Excel 2003 and SPSS 9.0 for Windows (Krebs, 1999). The Bray Curtis Cluster analysis in the programme BioDiversity Pro 2.0 was used to determine the similarities of the sampling stations and months to evaluate the distribution of the benthic macroinvertebrate species and the physicochemical features (McAleece et al., 1997). The Shannon-Wiener Index was used to evaluate the species diversity of the dam lake (Krebs, 1999).

\section{RESULTS AND DISCUSSION}

In the study period, a total of 30 taxa consisting of 1,295 individuals per $\mathrm{m}^{2}$ on average were determined. The identified specimens were grouped as "Oligochaeta", "Chironomidae", "Gastropoda" and "Other Insecta". A total of 5 species were identified, belonging to Oligochaeta (composed of 408 ind. $/ \mathrm{m}^{2}$ ), 15 taxa belonging to Chironomidae, (composed of $127 \mathrm{ind} . / \mathrm{m}^{2}$ ), belonging to Gastropoda (composed of 3 ind. $/ \mathrm{m}^{2}$ ) and 9 taxa belonging to Other Insecta (composed of $757 \mathrm{ind} . / \mathrm{m}^{2}$ ) (Table 1). It was concluded that Other Insecta make up the largest proportion of the lake's benthic macroinvertebrate fauna, accounting for $58.47 \%$ of the fauna. Other Insecta was followed by Oligocheta, Chironomidae, Gastropoda accounting for 31.50\%, 9.80\%, and $0.23 \%$ abundance, respectively (Table 1 ). The most taxa were identified at station 4 with 23 taxa. This was followed by station 2, station 3 and station 1 with 12, 9 and 8 taxa, respectively (Table 2). All the identified taxa were the first recorded for the Kanak Dam Lake. Oligochaeta and Chironomidae species are one of the most important freshwater species and are important food resources for some benthic macroinvertebrates and fishes (Brinkhurst \& Jamieson, 1971). Numerous studies have shown a correlation between the population of Chironomidae and the number of diverse species of Oligochaeta, and this correlation was observed to be negative (Darby, 1962; Ponyı, 1983). In these studies, Oligochaeta was found to be the dominant group when larval Chironomids were found at a low density. This result is consistent with the findings of the studies that have been conducted at various dam lakes in Turkey so far. In a study conducted by Kırgız (1988), it was reported that Oligochaeta had an abundance level of $18.16 \%$ while Chironomidae had $77.27 \%$ in Seyhan Dam Lake of the Adana Province of Turkey. In another study conducted at Lake Terkos in the Istanbul province, a contrasting result was reported, that Oligochaeta was the dominant group in the lake (82\% Oligochaeta, 10\% Chironomidae and 8\% other groups) Çamur-Elipek (2003). Further, in a study by Balık et al. (2004), Chironomidae was found as the dominant group with a $86.50 \%$ abundance, while Oligochaeta was found to have a $8.72 \%$ abundance in Buldan Reservoir of the Denizli province. In the Kemer Dam Lake of the Aydın Province, Oligochaeta was found to be the dominant group with 10 taxa while Chironomidae was found 
Table 1. Monthly distribution of benthic macroinvertebrates (ind $/ \mathrm{m}^{2}$ )in Kanak Dam Lake.

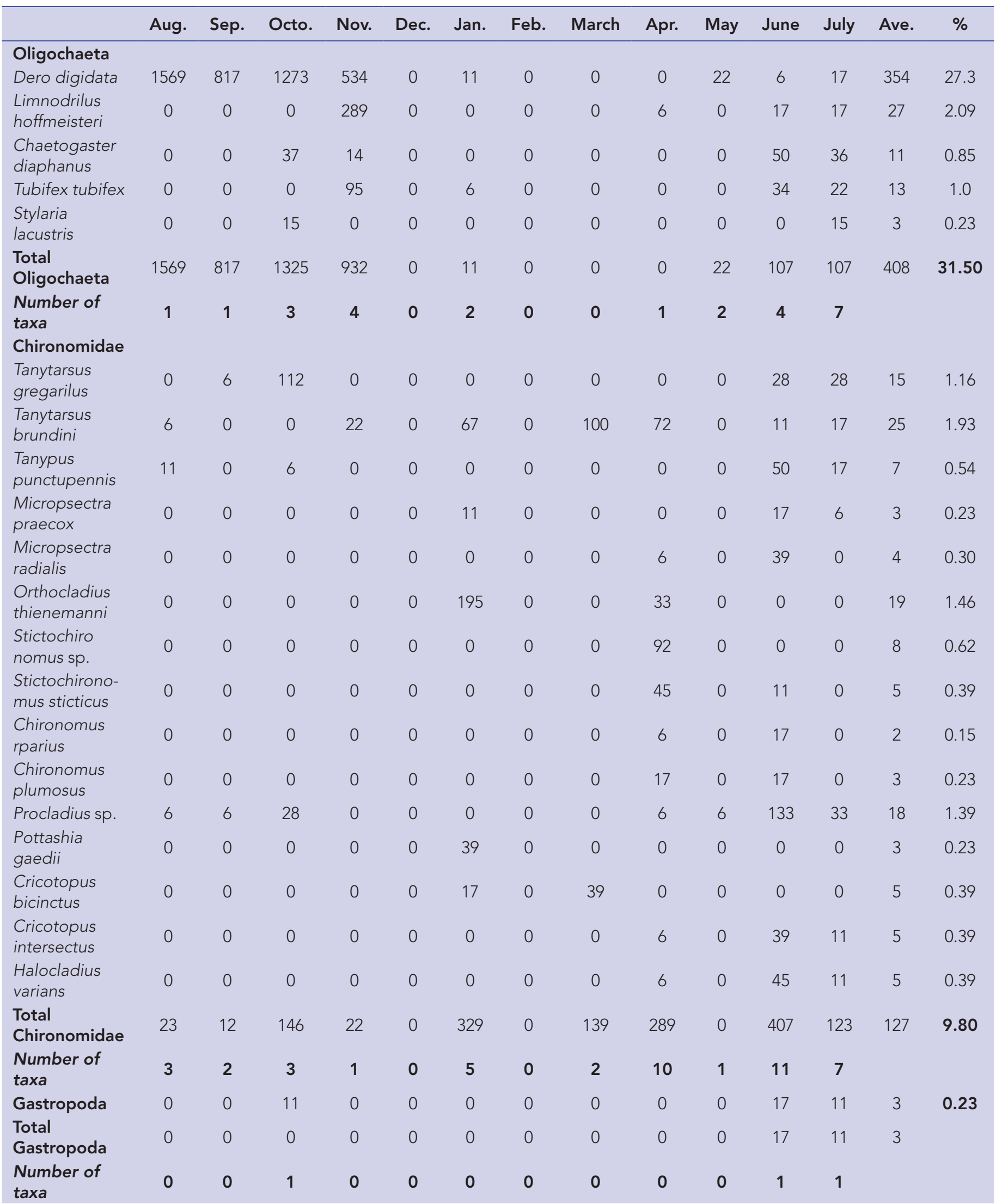


Table 1. (continued).

\begin{tabular}{|c|c|c|c|c|c|c|c|c|c|c|c|c|c|c|}
\hline Taxa & Aug. & Sep. & Octo. & Nov. & Dec. & Jan. & Feb. & March & Apr. & May & June & July & Ave. & $\%$ \\
\hline $\begin{array}{l}\text { Hemiptera } \\
\text { (adult) }\end{array}$ & 0 & 34 & 11 & 0 & 0 & 0 & 0 & 161 & 1797 & 6 & 23 & 50 & 174 & 13.44 \\
\hline $\begin{array}{l}\text { Total } \\
\text { Hemiptera }\end{array}$ & 0 & 34 & 11 & 0 & 0 & 0 & 0 & 161 & 1797 & 6 & 23 & 50 & & \\
\hline $\begin{array}{l}\text { Number of } \\
\text { taxa }\end{array}$ & 0 & 1 & 1 & 0 & 0 & 0 & 0 & 1 & 1 & 1 & 1 & 1 & & \\
\hline Trichoptera & 11 & 6 & 45 & 6 & 0 & 100 & 0 & 80 & 45 & 34 & 51 & 51 & 36 & 2.78 \\
\hline $\begin{array}{l}\text { Total } \\
\text { Trichoptera }\end{array}$ & 11 & 6 & 45 & 6 & 0 & 100 & 0 & 80 & 45 & 34 & 51 & 51 & & \\
\hline $\begin{array}{l}\text { Number of } \\
\text { taxa }\end{array}$ & 1 & 1 & 1 & 1 & 0 & 1 & 0 & 1 & 1 & 1 & 1 & 1 & & \\
\hline \multicolumn{15}{|l|}{$\begin{array}{l}\text { Ephemerop- } \\
\text { tera }\end{array}$} \\
\hline Baetis sp. & 0 & 0 & 0 & 0 & 0 & 6 & 0 & 0 & 0 & 0 & 17 & 11 & 3 & 0.23 \\
\hline $\begin{array}{l}\text { Total Ephem- } \\
\text { eroptera }\end{array}$ & 322 & 1445 & 1305 & 3144 & 0 & 28 & 0 & 28 & 11 & 45 & 67 & 39 & 536 & \\
\hline $\begin{array}{l}\text { Number of } \\
\text { taxa }\end{array}$ & 1 & 1 & 1 & 1 & 0 & 2 & 0 & 1 & 1 & 2 & 3 & 2 & & \\
\hline \multicolumn{15}{|l|}{ Odonata } \\
\hline Anizoptera & 0 & 0 & 0 & 0 & 0 & 6 & 0 & 0 & 0 & 6 & 11 & 17 & 3 & 0.23 \\
\hline Zygoptera & 0 & 6 & 0 & 0 & 0 & 0 & 0 & 0 & 0 & 0 & 17 & 6 & 2 & 0.16 \\
\hline Total Odonata & 0 & 6 & 0 & 0 & 0 & 6 & 0 & 0 & 0 & 6 & 28 & 23 & & \\
\hline $\begin{array}{l}\text { Number of } \\
\text { taxa }\end{array}$ & 0 & 1 & 0 & 0 & 0 & 1 & 0 & 0 & 0 & 1 & 2 & 2 & & \\
\hline Total Insecta & 356 & 1485 & 1361 & 3150 & 0 & 190 & 0 & 269 & 1853 & 85 & 186 & 163 & 757 & 58.47 \\
\hline $\begin{array}{l}\text { Number of } \\
\text { taxa }\end{array}$ & 6 & 7 & 10 & 7 & 0 & 13 & 0 & 5 & 14 & 7 & 26 & 19 & 1295 & \\
\hline
\end{tabular}

to have only 2 taxa (Yıldız et al., 2008). In this study, Dero digidata, belonging to Oligochaeta, was found to have the highest abundance level at all the sample-taking stations (86.76\%) while Stylaria lacustris was found to have the lowest abundance level $(0.74 \%)$. Dero digitata is known to be a cosmopolitan species and prefers a sandy-muddy substrate. In a study conducted in the Lakes Region, Yıldız \& Balık (2006) reported that Dero digitata were the most dominant organisms in the region and the second most dominant organism in the Topçam Dam Lake. It is possible to state that Dero digitata mostly prefers to live in human-made environments (Taşdemir et al., 2009). Our findings support the scientific literature surrounding these claims.

In this study, it was observed that Procladius (Holotanypus) sp., belonging to Chironomidae, had the highest abundance out of all the sampling stations with an abundance level of $14.18 \%$, while Stictochironomus stictus was found to have the lowest abundance with an abundance level of $1.57 \%$. Procladius (Holotanypus) sp. prefers muddy substrates in stagnant or slow flowing water bodies, especially in pools and small lakes (Rosenberg \& Resh, 1993; Armitage et al., 1995). The species has been identified in previous studies conducted at various dam lakes (Çamur Elipek 2003; Balık et al., 2004; Arslan et al., 2007; Yıldız et al., 2008; Taşdemir et al., 2010; Özbek et al., 2016). Chironomidae (e.g. Chironomus plumosus) is a common freshwater species, often regarded as an indicator of organic pollution (Brinkhurst \& Jamieson, 1971) In this study, it was found that C. plumosus have a low abundance level (2.36\%).

In this study Gastropoda was found to be present at only station 2 (Table 2). It has been reported that the species of Gastropoda 
Table 2. The distribution of benthic macroinvertebrates (ind. $/ \mathrm{m}^{2}$ ) in Kanak Dam Lake in terms of the sampling stations.

\begin{tabular}{|c|c|c|c|c|c|}
\hline & $1^{\text {st }}$ & $2^{\text {nd }}$ & $3^{\text {rd }}$ & $4^{\text {th }}$ & $\%$ \\
\hline \multicolumn{6}{|l|}{ Oligochaeta } \\
\hline Dero digidata & 146 & 418 & 493 & 357 & 86.76 \\
\hline $\begin{array}{l}\text { Limnodrilus } \\
\text { hoffmeisteri }\end{array}$ & 35 & 0 & 0 & 9 & 6.61 \\
\hline $\begin{array}{l}\text { Chaetogaster } \\
\text { diaphanus }\end{array}$ & 0 & 17 & 17 & 9 & 2.70 \\
\hline Tubifex tubifex & 17 & 0 & 0 & 0 & 3.19 \\
\hline $\begin{array}{l}\text { Stylaria } \\
\text { lacustris }\end{array}$ & 0 & 13 & 13 & 0 & 0.74 \\
\hline $\begin{array}{l}\text { Total } \\
\text { Oligochaeta }\end{array}$ & & 0 & & 0 & 100 \\
\hline \multicolumn{6}{|l|}{ Chironomidae } \\
\hline $\begin{array}{l}\text { Tanytarsus } \\
\text { gregarilus }\end{array}$ & 15 & 43 & 0 & 0 & 11.82 \\
\hline $\begin{array}{l}\text { Tanytarsus } \\
\text { brundini }\end{array}$ & 0 & 0 & 0 & 98 & 19.69 \\
\hline $\begin{array}{l}\text { Tanypus } \\
\text { punctupennis }\end{array}$ & 0 & 11 & 11 & 0 & 5.51 \\
\hline $\begin{array}{l}\text { Micropsectra } \\
\text { praecox }\end{array}$ & 0 & 0 & 0 & 11 & 2.36 \\
\hline $\begin{array}{l}\text { Micropsectra } \\
\text { radialis }\end{array}$ & 0 & 0 & 0 & 17 & 3.14 \\
\hline $\begin{array}{l}\text { Orthocladius } \\
\text { thienemanni }\end{array}$ & 0 & 0 & 0 & 76 & 14.96 \\
\hline $\begin{array}{l}\text { Stictochirono- } \\
\text { mus sp. }\end{array}$ & 0 & 0 & 0 & 30 & 6.30 \\
\hline $\begin{array}{l}\text { Stictochirono- } \\
\text { mus sticticus }\end{array}$ & 0 & 0 & 0 & 19 & 3.93 \\
\hline $\begin{array}{l}\text { Chironomus } \\
\text { rparius }\end{array}$ & 0 & 0 & 0 & 7 & 1.57 \\
\hline $\begin{array}{l}\text { Chironomus } \\
\text { plumosus }\end{array}$ & 0 & 0 & 0 & 11 & 2.36 \\
\hline Procladius sp. & 13 & 28 & 26 & 19 & 14.18 \\
\hline $\begin{array}{l}\text { Pottashia } \\
\text { gaedii }\end{array}$ & 0 & 0 & 0 & 13 & 2.36 \\
\hline $\begin{array}{l}\text { Cricotopus } \\
\text { bicinctus }\end{array}$ & 0 & 0 & 0 & 18 & 3.94 \\
\hline $\begin{array}{l}\text { Cricotopus } \\
\text { intersectus }\end{array}$ & 0 & 18 & 0 & 0 & 3.94 \\
\hline $\begin{array}{l}\text { Halocladius } \\
\text { varians }\end{array}$ & 0 & 0 & 0 & 20 & 3.94 \\
\hline $\begin{array}{l}\text { Total } \\
\text { Chironomidae }\end{array}$ & & 0 & & 0 & 100 \\
\hline Gastropoda & 0 & 13 & 0 & 0 & 1 \\
\hline $\begin{array}{l}\text { Total } \\
\text { Gastropoda }\end{array}$ & 0 & 13 & 0 & 0 & 100 \\
\hline \multicolumn{6}{|l|}{ Other Insecta } \\
\hline $\begin{array}{l}\text { Hemiptera } \\
\text { (adult) }\end{array}$ & 11 & 74 & 599 & 11 & 22.98 \\
\hline Trichoptera & 13 & 28 & 14 & 85 & 4.75 \\
\hline
\end{tabular}

Table 2. (continued).

\begin{tabular}{lccccc}
\hline $\begin{array}{l}\text { Number of } \\
\text { taxa }\end{array}$ & $\mathbf{8}$ & $\mathbf{1 2}$ & $\mathbf{9}$ & $\mathbf{2 3}$ & \\
$\begin{array}{l}\text { Ephemerop- } \\
\text { tera }\end{array}$ & & & & & \\
Heptogenia & 0 & 0 & 0 & 9 & 0.27 \\
Caenidae & 139 & 620 & 96 & 1269 & 70.14 \\
Baetis sp. & 0 & 0 & 0 & 11 & 0.40 \\
Anizoptera & 0 & 0 & 0 & 13 & 0.40 \\
Zygoptera & 0 & 11 & 0 & 0 & 0.27 \\
Plecoptera & 0 & 0 & 0 & 17 & 0.52 \\
Coleoptera & 0 & 0 & 0 & 9 & 0.27 \\
(larvae) & & & & & 100 \\
Total Insecta & & 1294 & $\mathbf{1 3 6 0}$ & $\mathbf{2 1 3 8}$ & \\
Total Number & 389 & 1294
\end{tabular}

are more intense in spring and summer and have a strong tolerance of hardness and salt (Robert \& Dillion, 1999). In our study, the specimens belonging to this group were found in June, July and October. It was identified in this study that while the other insecta group comprised $58.47 \%$ of the macrobenthicfauna, Caenidae represented $70.14 \%$ of the fauna during the sampling period. The other insecta group collected from the lake was found to consist of 9 taxa (Table 1). Caenidae, Hemiptera and Trichoptera were observed at all stations. Caenidae had the highest number of individuals at station 4 with 1,269 ind. $/ \mathrm{m}^{2}$, it had the lowest number of individuals at station 3 with 96 ind. $/ \mathrm{m}^{2}$. Heptogenia, Anizoptera and Coleoptera larvae were found to have the lowest abundance $(0.27 \%$ ) within this group (Table 2). Ephemeroptera require a moderate amount of dissolved oxygen in the water and prefer clean water, but they can occasionally survive in a low amount of dissolved oxygen. Ephemeroptera belong to the feeding group of grazers and feed on algae or detritus (Haldar et al., 2016). Hemiptera was found to have the highest number at station 3 with 599 ind. $/ \mathrm{m}^{2}$ and having the lowest number of individuals with $11 \mathrm{ind} . / \mathrm{m}^{2}$ at station 1 and station 4 (Table 1 and Table 2). Trichoptera was found to have an abundance of $4.75 \%$ within this group. It was found that station 4 had the highest number of individuals per meter square with 85 and station 1 had the lowest with 13 (Table 2). Trichoptera are a good indicator of pollution-free water as they dwell in clean water and are very sensitive to polluted water. They can be found anywhere from warm streams to cool streams including lakes, ponds and marshes (Haldar et al., 2016). In this study the dissolved oxygen value of the dam lake was found to have first class water quality (Table 3). Zygoptera, belonging to Odonata, was found to have the lowest abundance $(0.27 \%)$ within this group (Table 2$)$. Odonata can survive in waters with a very low amount of dissolved oxygen and therefore are found in areas where there is a moderate amount of pollution. They belong to the feeding group of predators (Haldar et al., 2016). Coleoptera larvae were found to have the lowest abundance $(0.27 \%)$ within this group (Table 2). Coleopterans larvae are pollution-sensitive and can be found in moderately polluted water (Haldar et al., 2016).

It is observed that Oligochaeta and Chironomidae are found at a lot of dam lakes.(Balık et al., 2004; Taşdemir et al., 2010; Ersan et 


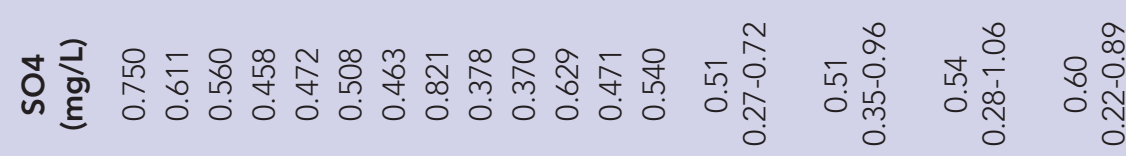

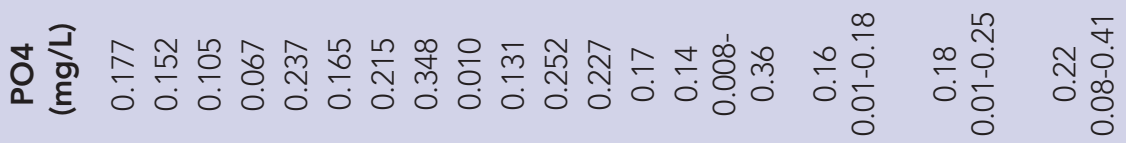

ż

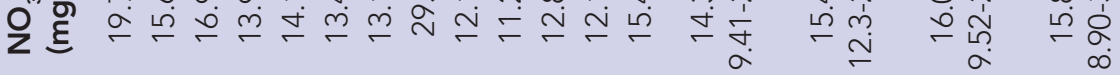

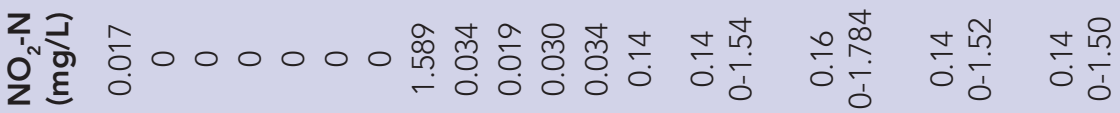

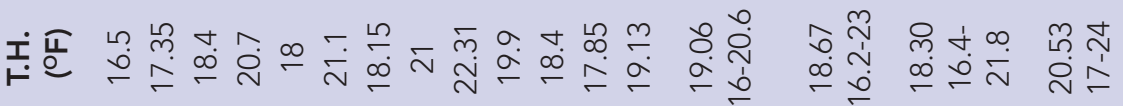

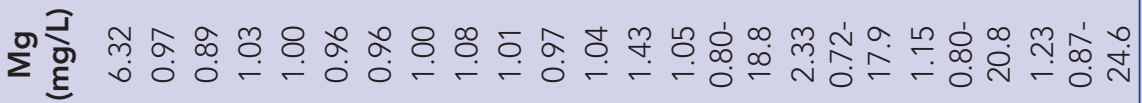

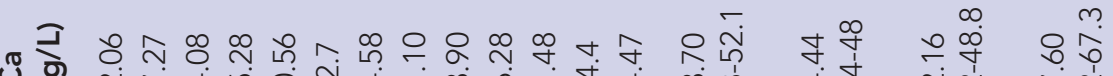

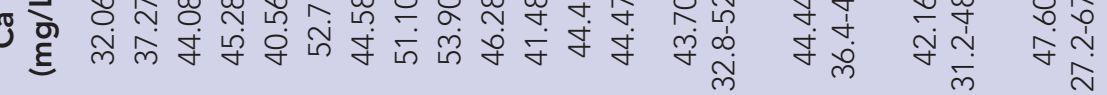

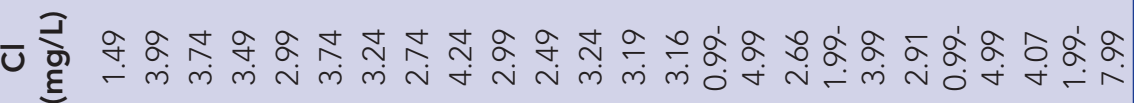

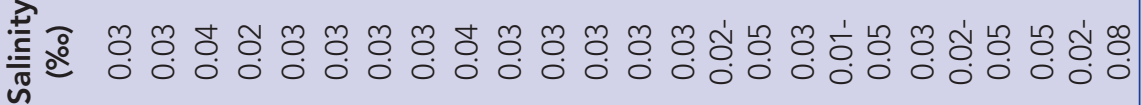

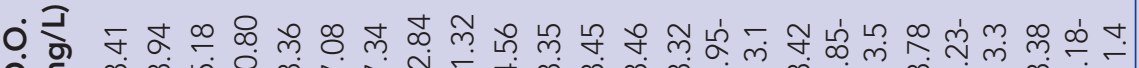

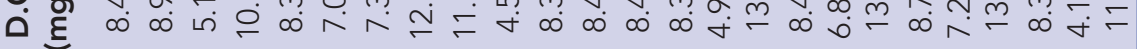

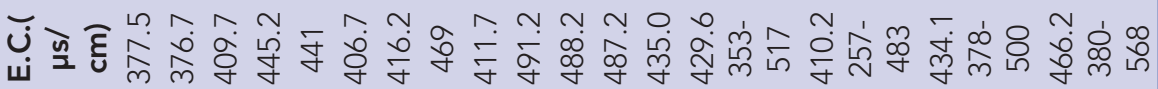

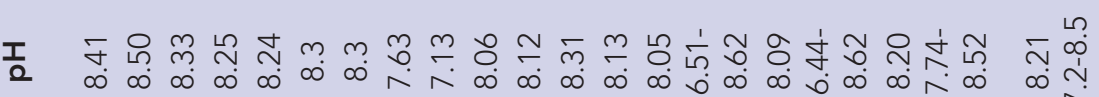

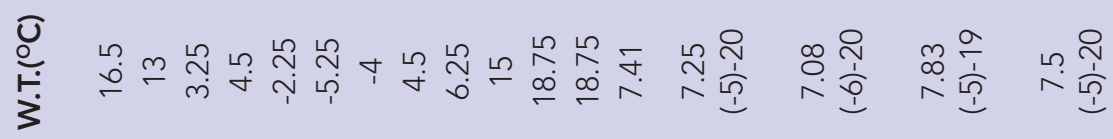

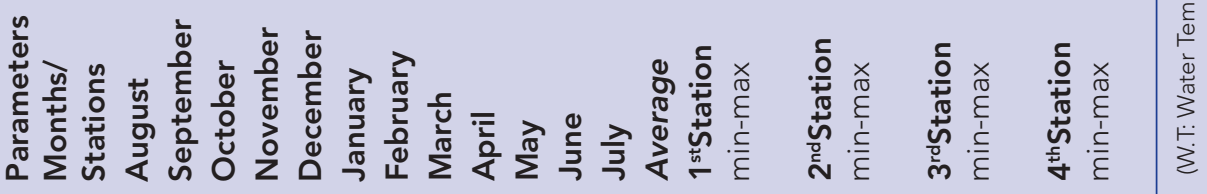


al., 2009; Yıldız et al., 2008; Arslan et al., 2007). Chironomidae was found as the dominant group in Buldan Reservoir (Denizli) (86.50\%, Chironomidae, $8.72 \%$ Oligochaeta and $4.77 \%$ Gastropoda) by Balık et al., (2004). In Tahtalı Dam Lake (İzmir), 82\%, Chironomidae, 17\% Oligochaeta, 1\% Amphipoda was reported by Taşdemir et al., (2010). In a study conducted at the Mamasin Dam Lake by Ersan et al., (2009), 86.23\% Chironomidae, 7.3\% Oligochaeta and 6.47\% Mollusca was reported. While Oligochaeta was found to be the dominant group in Kemer Dam Lake (Aydın) (92.72\%), Chironomidae was found to have an abundance level of $7.28 \%$ (Yıldız et al., 2008). In a study conducted at the Musaözü Dam Lake (Eskişehir) by Arslan et al. (2007), Oligochaeta was found to have 42,5\% abundance while Chironomidae larvae and the Varia were observed to have abundance levels of $30.5 \%$ and $27 \%$, respectively. In the Kanak Dam Lake the other Insecta group was found as the dominant group. This may be due to either the high water quality observed in the dam that can maintain the life cycle of insects, or it may be related to the age of the dam. In a study conducted at the Sarıkum Lake (Sinop) by Akbulut et al. (2002) the other insecta group was found to be the dominant group.

The monthly physicochemical characteristics of the lake water are presented in Table 3. According to the water quality class levels in Anonymous (2016), the temperature, $\mathrm{pH}$, electrical conductivity, dissolved oxygen, chloride and $\mathrm{SO}_{4}$ levels of water were found at first class water quality (Table 3). However, the $\mathrm{NO}_{3}-\mathrm{N}$, $\mathrm{NO}_{2}-\mathrm{N}$ and $\mathrm{PO}_{4}$ levels of the water were found at second and third class water quality level. The total hardness of water was found to be light hard ( $\left.{ }^{\circ} \mathrm{F}\right)$ water quality level in Kanak Dam Lake.

Water temperature is the most important factor affecting the biologic activities of benthic macroinvertebrates in the lakes. The water temperature level of the Kanak Dam Lake fluctuated between $-6^{\circ} \mathrm{C}$ and $20^{\circ} \mathrm{C}$ during the study period. This fluctuation was caused by seasonal temperature changes in the weather. Similar physicochemical results were found in various studies conducted at the dam lakes in the region so far Dirican (2008); Mutlu et al., (2014); Dirican (2015); Yıldız \& Karakuş (2018).

$\mathrm{pH}$ is a measure of how acidic or basic water is. The $\mathrm{pH}$ value of the lake water was found to be between 6.44 and 8.62. The pH value did not vary much among the stations (Table 3). In the study performed in Kılıçkaya Dam Lake (Sivas) and in the Çamlıgöze Dam Lake (Sivas), it were reported that both lakes have first class quality (Dirican 2008; Dirican 2015). In another other study which was performed by Mutlu et al. (2014) in Karacalar Dam Lake (Ulaş-Sivas), it was reported that the lake water had a pH level of 8.33 on average. Further, in the 4 Eylül Dam Lake (Sivas) by Yıldız \& Karakuş (2018) the $\mathrm{pH}$ level of the surface water was reported to be 7.73 on average.

Electrical conductivity (EC) is a measure of water's capability to transmit electric current. The electrical conductivity of water depends on the presence, total concentration, mobility, valence and relative change of ions in water as well as water temperature. The electrical conductivity of water is positively correlated with water temperature (Hem, 1985). The electrical conductivity level of the Kanak Dam Lake water was observed to have values ranging from $257 \mu \mathrm{s} / \mathrm{cm}$ to $568 \mu \mathrm{s} / \mathrm{cm}$. The highest value of EC was re- corded at station 4 (Table 3). This station is the point where the Kanak stream meets the dam lake. The pollution from the stream may have increased when combined with the dam. EC value may be high due to pollution. In a study conducted by Dirican (2008) at the Kılıçkaya Dam Lake, the EC level of the water was observed to be between $344 \mu \mathrm{mhos} / \mathrm{cm}$ and $364 \mu \mathrm{mhos} / \mathrm{cm}$. In another study conducted at 4 Eylül Dam Lake, the researchers reported that the surface water had an EC level of $181.5 \mu \mathrm{s} / \mathrm{cm}$ Yıldız \& Karakuş (2018).

The dissolved oxygen level of water is an important factor for aquatic life and the chemical characteristics of the aquatic environment. In inland ecosystems, the minimum dissolved oxygen should not be less than $5 \mathrm{mg} / \mathrm{L}$ for aquatic life (Egemen, 2011). In the Kanak Dam Lake, the dissolved oxygen level was observed to fluctuate between $4.18 \mathrm{mg} / \mathrm{L}$ to $13.51 \mathrm{mg} / \mathrm{L}$ during the study period. The dissolved oxygen levels did not vary much among the stations (Table 3). In a study which was performed at Kılıçkaya Dam Lake, the dissolved oxygen level was reported to range from $8.64 \mathrm{mg} / \mathrm{L}$ to $8.94 \mathrm{mg} / \mathrm{L}$ Dirican (2008). In another research conducted at the Çamlıgöze Dam Lake, the water was observed to have first class quality level (Dirican, 2015). Further, in the Karacalar Dam Lake, it was reported that dissolved oxygen was $11.12 \mathrm{mg} / \mathrm{L}$ on average (Mutlu et al., 2014). In a study conducted by Yıldız \& Karakuş (2018), it was reported that the dissolved oxygen amount in surface waters was found to be 7.88 on average.

Salinity refers to the total concentration of dissolved inorganic ions in water or soil and is therefore a component of all waters (Williams \& Sherwood, 1994). The average salinity level at the Kanak Dam Lake was found to be $0.01 \%$ during the study period. The salinity levels did not vary much among the stations (Table 3). In the Karacalar Dam Lake, the salinity level was reported to be 0.011 ppt on average (Mutlu et al., 2014).

Chloride is an important chemical found in all natural waters, generally at a low concentration (Taş, 2011). The chloride level at the Kanak Dam Lake was observed to vary between $0.99 \mathrm{mg} / \mathrm{L}$ to $7.99 \mathrm{mg} / \mathrm{L}$ in the study period. These findings are consistent with the findings of various studies conducted at the freshwater environments in the region. At the Kılıçkaya Dam Lake (Sivas), the chloride level of the lake water was reported to have first class quality level Dirican (2008); and the Karacalar Dam Lake (Sivas) was reported to have a chloride level ranging from $9.20 \mathrm{mg} / \mathrm{L}$ to $20.08 \mathrm{mg} / \mathrm{L}$ (Mutlu et al. 2014). Our results were similar to the other studies which have been performed in the freshwater environments of the region.

Magnesium ions cause water hardness. As magnesium is one of the atoms in the molecular structure of chlorophyll, it is significantly important for plants with chlorophyll. It also regulates the phosphorus mechanism in algae and plants. In freshwaters, the magnesium limit is $50 \mathrm{mg} / \mathrm{L}$ (Taş, 2011). The magnesium level in the Kanak Dam Lake was observed to range from $0.72 \mathrm{mg} / \mathrm{L}$ to $24.6 \mathrm{mg} / \mathrm{L}$. Calcium has the highest abundance out of all metals in freshwaters and it is biologically very important. Calcium forms the skeletal structure of aquatic organisms (Bulut et al., 2010). It also, just like magnesium, causes water hardness. In the Kanak Dam Lake, the calcium level was found to fluctuate between 27.2 
$\mathrm{mg} / \mathrm{L}$ to $67.33 \mathrm{mg} / \mathrm{L}$ during the study period. These findings are consistent with the findings of similar studies performed in the region. Mutlu et al., (2014) reported that they found calcium levels of $26.26 \mathrm{mg} / \mathrm{L}$ and magnesium of levels $23.27 \mathrm{mg} / \mathrm{L}$ in their study at the Karacalar Dam Lake. In the study which was performed by Dirican (2015) in Çamlıgöze Dam Lake the water could be classified as moderately hard in terms of total hardness.

Nitrogen derivatives such as $\mathrm{NO}_{2}, \mathrm{NO}_{3}$ and $\mathrm{NH}_{4}{ }^{+}$play an important role in the process of water pollution. The nitrite resources in waters are the organic compounds, fertilizers and minerals (Taş, 2011). $\mathrm{NO}_{3}$ is the final product of nitrogenous organic minerals (Topal \& Topal-Arslan, 2012). During the study period, the $\mathrm{NO}_{2}-\mathrm{N}$ level in the Kanak Dam Lake was observed to fluctuate between $0 \mathrm{mg} / \mathrm{L}$ to $1.784 \mathrm{mg} / \mathrm{L}$, while the $\mathrm{NO}_{3}-\mathrm{N}$ level ranged from 8.90 $\mathrm{mg} / \mathrm{L}$ to $33.6 \mathrm{mg} / \mathrm{L}$. In a study performed by Dirican (2008) at the Kilıçkaya Dam Lake and in a study conducted by Mutlu et al., (2014) at the Karacalar Dam Lake, the $\mathrm{NO}_{2}-\mathrm{N}$ and $\mathrm{NO}_{3}-\mathrm{N}$ levels were reported to have first class quality.

Phosphorus is a necessary element for aquatic life. Phosphorus is the most basic element of eutrophication occurring in water (Harper, 1992). It is found in very small amounts in uncontaminated waters and determines the richness of lakes (Tepe \& Boyd, 2003). In the Kanak Dam Lake, $\mathrm{PO}_{4}$ level was reported to fluctuate between $0.0008 \mathrm{mg} / \mathrm{L}$ and $0.41 \mathrm{mg} / \mathrm{L}$ during the study period. In a study performed by Mutlu et al. (2014), the phosphorus level was reported to be between $0.001 \mathrm{mg} / \mathrm{L}$ and $0.017 \mathrm{mg} / \mathrm{L}$ in Karacalar Dam Lake.

The $\mathrm{SO}_{4}$ level in Kanak Dam Lake was found to be significantly low during the study period, between $0.22 \mathrm{mg} / \mathrm{L}$ and $1.06 \mathrm{mg} / \mathrm{L}$. In the studies performed by Dirican (2008 and 2015), the levels of sulphate were reported to be first class in Kilıçkaya Dam Lake and Çamlıgöze Dam Lake. Our findings are similar to the findings of the previous studies conducted in the region. The results obtained from the Shannon Weiner index suggest that the Kanak Dam Lake's macroinvertebrate diversity is not significantly high (Average $H^{\prime}$ : 0.64). The Shannon Weiner values obtained from sampling stations were found to be close to each other. The diversity level was found to be $H^{\prime}$ : 0.67 for station $1, H^{\prime}$ : 0.63 for station 2, $\mathrm{H}^{\prime}: 0.60$ for station 3 , and $\mathrm{H}^{\prime}: 0.68$ for station 4 . The results were obtained using the Bray-Curtis index and indicated that in the Kanak Dam Lake, July and June are the most similar months in terms of the physicochemical parameters of the lake water with $99.45 \%$, similarity level followed by May and June with 98.37\%, and January and February with $97.75 \%$. August and May were observed to be the most different months (Figure 2). Further, results of the Bray-Curtis index indicated that in terms of the distribution of taxa at different sampling stations, September and October, August and October, September and November are very similar to each other with $83.32 \%, 67.86 \%, 61.79 \%$ similarity levels, respectively. August and February were found to be the most different months in terms of distribution of the taxa with $0 \%$ similarity level. (Figure 3). In terms of the composition taxa, station 2 and station 4 were found most similar to each other with $60.83 \%$ similarity level followed by station 2 and station 3 with a similarity level of $52.20 \%$ similarity, while station 1 and station 2 were found to be the most different with a $40.04 \%$ similarity level (Figure 4). This situation can be explained by the bottom struc-

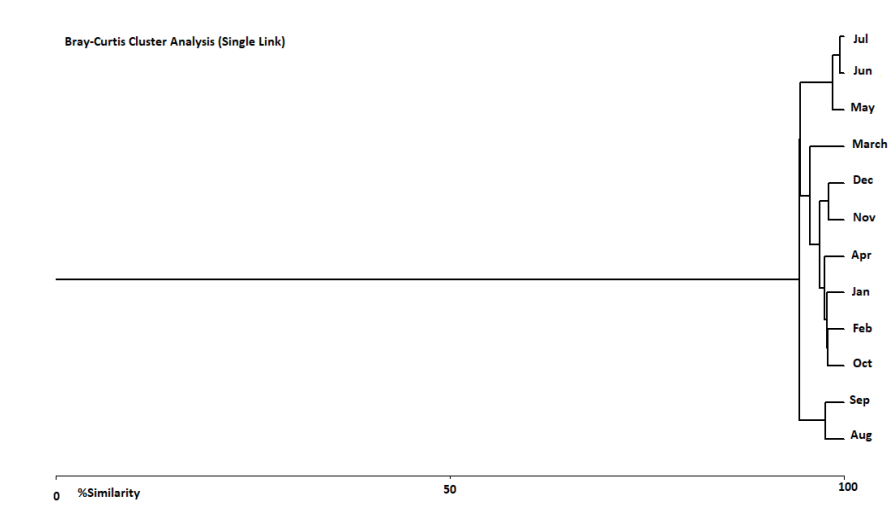

Figure 2. The dendrogram of similarity of months in Kanak Dam Lake in respect of physicochemical parameters.

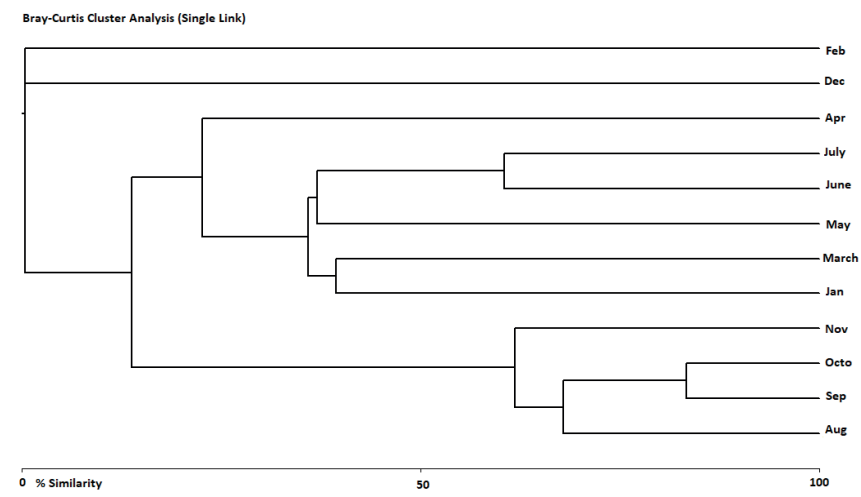

Figure 3. The dendrogramof similarity of months in Kanak Dam Lake in respect of macrobenthic invertebrates.

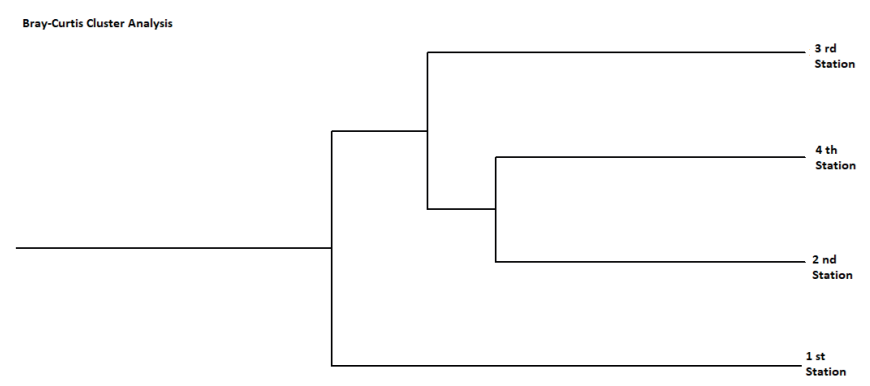

\% Similarity 50 100

Figure 4. The dendrogramof similarity of stations in Kanak Dam Lake in respect to macrobenthic invertebrates.

ture (rich vegetation) of these stations. As a result of this study, macrobenthic invertebrate fauna of the reservoir, which has never been studied before, was determined. Similar studies should be repeated periodically so as to predict the future of dam lakes.

\section{CONCLUSION}

With this study, we aimed to determine some physicochemical properties and benthic macroinvertebrate fauna of Kanak Dam 
Lake. As a result of the research, 1,295 ind. $/ \mathrm{m}^{2}$ and 30 taxa were identified. It was observed that the benthic macroinvertebrates were presented as Other Insecta group > Oligochaeta group > larval Chironomidae group > Gastropoda group. The identified taxa were the first recorded for the lake. In terms of the parameters examined, the lake was found to be between the first and second class water quality.

Conflict of interests: The authors declare that they have no conflict of interest.

Ethics committee approval: Ethics committee approval was not required.

Funding: This research has been supported by the Cübap SMYO-004 project. The authors thank Dr. Gazel Burcu Aydın (Trakya University) for Chironomidae diagnosis.

\section{Acknowledgments: -}

\section{Disclosure: -}

\section{REFERENCES}

Ahıska, S. (1999). The Benthic Fauna of Kesikköprü (Ankara) Dam Lake and Seasonal Dynamics (in Turkish with English abstract). Ankara University Instute of Science and Tecnology Department of Biology. PhD Thesis, Ankara.78 p.

Anonymous. (2016). Surface water quality control regulation. Official Gazette No: 29797 of 10 August 2016, Ankara.

Armitage, P. D., Cranston, P. S. \& Pinder, L. C. V. (1995). The Chironomidae: biology and ecology of non-biting midges. Chapman \&Hall, London, $572 \mathrm{p}$.

Akbulut, M., Öztürk, M. \& Öztürk, M. (2002). The Benthic Macroinvertebrate Fauna of Sarıkum Lake and Spirng waters (Sinop). Turkish Journal of Marine Sciences, 8, 102-119.

Arslan, N., Illhan, S., Şahin, Y., Filik, C., Yılmaz, V. \& Öntürk, T., (2007). Diversity of invertebrate Fauna in Littoral of Shallow Musaözü Dam Lake in Comparison with Environmental Parameters. Journal of Applied Biological Sciences, 1(3), 67-75.

Balık, S., Ustaoğlu, M. R., Özbek, M., Taşdemir, A., \& Yıldız, S. (2004). Buldan Dam Lake (Denizli, Turkey) Benthic Fauna. Ege Journal of Fisheries and Aquatic Sciences, 21(1-2), 139-141.

Brinkhurst, O. R (1971). British Aquatic Oligochaeta. Univ.Toronto Press, Toronto.

Brinkhurst, R. O (1978). Limnofauna Europaea, Illies J., Gustav Fisher Verlag, Stutgart,pp: 139-147.

Brinkhurst, R. O. \& Jamieson, B.G.M (1971). Aquatic Oligochaeta of the World, Oliver Boyd, Edinburg.

Brinkhurst, R. O. \& Wetzel, M. J. (1984). Aquatic Oligochaeta of the World: Supplement, A Catalogue of New Freshwater Species, Descriptions and Revisions, 44, Canadian Technical Report of Hydrography and Ocean Sciences, Canada.

Bulut, C., Akçimen, U. K., Küçükkara, R. \& Savaşer, S. (2010). Karanfilliçay Deresi suyunun fiziko-kimyasal ve mikrobiyolojik parametrelerinin mevsimsel değişimi ve akuakültür açısından değerlendirrilmesi. Dumlupınar Üniversitesi Fen Bilimleri Enstitüsü Dergisi, 21, 7, 3055.

Cranston, P. S. (1982). A Key to the Larvae of the British., Orthocladiinae. Freshwater Biological Association Scientific Publication 4, 152 pp.

Darby, R. E. 1962. Midges associated with California rice field, with special reference to their ecology (Diptera: Chironomidae). Hilgardia, 32, 1-206. [CrossRef]
Dirican, S., (2008). Kılıçkaya BarajGölü (Sivas-Türkiye)'nin fzikokimyasal özelliklerinin gökkuşağı alabalığı yetiştiriciliği için değerlendirilmesi, Kafkas Üniversitesi Fen Bilimleri Dergisi, 1(2), 11-21.

Dirican, S. (2015). Assesment od water quality using physicochemical parameters of Çamlıgöze dam lake in Sivas. Turkey, Ecologia, 5(1), 1-7. [CrossRef]

DSi (2016). State Hydraulic Works. Date of access: 30.12.2016, http:// www.dsi.gov.tr/

Egemen, O. \& Sunlu, U. (1999). Water quality. Ege University Fisheries Faculty Issue number: 14, İzmir. ISBN: 9754831416.

Egemen, O. (2011). Water Quality. Ege University Fisheries Faculty Issue Number:14, İzmir.

Ersan, E., Altındağ, A., Ahıska, S. \& Alaş, A. (2009). Zoobenthic fauna and seasonal changes of Mamasin dam lake (Central part of Turkey). African Journal of Biotechnology, 8 (18), pp. 4702-4707.

Fındık, Ö. \& Göksu, M. Z. L. (2004). Benthic fauna of Berdan Dam Lake (içel). Menba Su Ürünleri Fakültesi Dergisi Araştırma, ISSN: 21472254.

Fittakau, E. J. \& Roback, S. S (1983). The Larvae of Tanypodinae (Diptera: Chironomidae) of Holoarctic Region:Keys and Diagnnoses. Entomologica Scandinavica Suppl. 19, 33-110.

Haldar, R., Kosankar, S., Sangolkar, L. N., (2016). Ecological significance of macro invertebrates as an indicator of environmental pollution. International Journal of Engineering Science and Computing, 6(11), 3302-3307.

Harper, D. 1992. Eutrophication of fresh waters: Principlers, problems and restoration. Chapman and Hall, London, UK.

Hem, J. D.(1985). Study and interpredation of the chemical characteristics of natural water: U.S. Geological Survey Water-Supply Paper 2254, U.S. Geological Survey, Alexandria, VA 22304, USA, p.263.

Kathman, R. D. \& Brinkhurst, R. O (1998). Guide to The Freshwater Oligochaetes of North America, Aquatic Resources Center, Tennessee, USA.

Kırgız, T. (1988). A morphological and Ecological study on the larvae of Chironomidae (Diptera) of Seyhan Dam Lake (in Turkish with English abstract). Doğa Turkish Journal of Zoology, 12(3), 231-245.

Krebs, C. J (1999). Ecological Methodology. Addison Wesley Longman, Menlo Park, California.

McAleece, N. Gage, J. D. G., Lambshead, P. J. D. \& Paterson, G. L. J. (1997). BioDiversity Professional statistic analysis software. Jointly developed by the Scottish Association for Marine Science and the Natural History Museum London.

McDonald, B. S., Mullins, G. W. \& Lewis, S. 1991. Macroinvertebrates as Indicators of Stream Health. The American Biology Teacher, Volume 53, No. 8. [CrossRef]

Merrit, C. K., 1984. An Illustration to the Aquatic Insects of North America (Second Edition) Merrit, Cummins Kendall/Hunt Publishing Company.

Milligian, D. \& Michael, R. (1997). Identification Manual for The Aquatic Oligochaeta of Florida Volume I, Freshwater Oligochaetes. State of Florida Department of Environmental Protection Tallahassee, Florida.

Mutlu, E., Kutlu, B., Yanık, T. \& Demir, T. (2014). Evaluation of water quality of Karacalar Dam Lake (Ulaş-Sivas) by using Physicochemical methods. Journal of Selçuk University Natural and Applied Science, Online ISSN:2147-3781, 30-40.

Oliver, D., R., McClymont, D., \& Roussel, M., E (1978). A Key to Some Larvae of Chironomidae (Diptera) From the Mackenzie and Porcupine River Watersheds, Biosystematics Research Institute, Ottowa, Canada.

Özbek, M., Taşdemir, A. \& Yıldız, S. (2016). Benthic macroinvertebrate of Adıgüzel Reservoir (Denizli, Turkey) (in Turkish with English abstract). Ege Journal of Fisheries and Aquatic Sciences, 33(3), 259-263. [CrossRef]

Ponyı, J. E., 1983. Quantative Studies on Chironomidae and Oligochaeta in the Benthos of Lake Balaton Arch Hydrobiol, 97, 196-207. 
Pinder, K. \& Resss F., (1983). The Larvae of Chironominae (Diptera:Chironomidae) of the Holoarctic Region- Keys and Diagnoses. Entomologica Scandinavica Suppl. 19, 293-435, Lund Sweden.

Robert, T., Dillion, J. R. 1999. The Ecology of Freshwater Molluscs, 561, 367-464.

Rosenberg, D. \& Resh, V. (1993). Freshwater Biomonitoring and Benthic Macroinvertebrates. Chapman \& Hall. New York.

Seather, O. A (1980). Glossary of Chironomid Morphology Terminology (Diptera:Chironomidae) Entomologica Scandinavica Suppl. 14, 51 pp. Lund Sweden.

Sperber, C. (1948). A Taxonomical Study of The Naididae. Zool. Bidrag, Uppsala, 28,1-296.

Sperber, C. (1950). A Guide For The Determination European Naididae, Zool Bidr, Uppsala 29, 45-78.

Taş, B. (2011) Gaga Gölü(Ordu, Turkey) su kalitesinin incelenmesi. Black Sea Technical University's Journal of Science, 1(3), 43-61.

Taşdemir, A., Yıldız, S., Özbek, M., Ustaoğlu, M. R. \& Balık, S. (2010). The macrobenthic (Oligochaeta, Chironomidae, Amphipoda) fauna of Tahtalı reservoir (Izmir) (in Turkish with English abstract). Journal of FisheriesSciences.com, 4(4): 376-383. [CrossRef]

Taşdemir, A. \& Ustaoğlu, M. R. (2005). Taxonomical investıgation of Lake District Inland Waters Chironomidae and Chaoboridae (Diptera). Ege University Journal of Fisheries \&Aquatic Sciences, 22(3-4), 377-384.

Tepe, Y., \& Boyd, C.E. 2003. A reassesment of nitrogen fertilization for sunfish ponds. Journal of World Aquaculture Society, 34(4), 505-511. [CrossRef]
Timm, T. (1999). A Guide to the Estonian Annelida Naturnalist's Handbooks 1, Estonian Acedemy Publishers, Tartu-Talinn.

Topal, M. \& Arslan-Topal, E. (2012). Elazığ İlinde bir Maden sahasında kaynaklanan sızıntı sularının maden çayına etkisi. Karaelmas Üniversitesi Journal of Science and Engineering, 2(1), 15-21. [CrossRef]

Wetzel, M. J., Kathman, R. D., Fend, S. V., \& Coates, K. A (2000). Taxonomy, Systematics and Ecology of Freshwater Oligochaeta. Workbook Prepared for North American Benthological Society Technical Workshop, 48th Annual Meeting, Keystone Resort.

Varol, M. (2015). Evaluation of Dicle Dam Lake Water Quality according to Water Pollution Control Regulation. Turkish Journal of Agriculture and Natural Sciences, 2(1), 85-91.

Yıldız, S., Tasdemir, A., Balık, S., \& Ustaoğlu, M. R (2008). Macrobentic (Oligochaeta, Chironomidae) Fauna of Kemer Dam Lake (Aydın). Journal of Fisheries Sciences.com, 2(3), 457-465. [CrossRef]

Yıldız, S., \& Balık, S. (2006). The Oligochaeta (Annelida) Fauna of Topçam Dam-Lake (Aydın, Turkey). Turkish Journal of Zoology, 30(83-89).

Yıldız, S. \& Karakuş, C. B. (2018). Mapping of water quality-level relation of Sivas 4 Eylül Dam with Geographic Information System (GIS). APJES 6-1:64-75.

Williams, W. D. \& Sherwod J. E. (1994).Definition and measurement of salinity in salt lakes, Inetrnational Salt Lake Resources, 3, 53-63. [CrossRef] 